Acta Universitatis Wratislaviensis • No 3869

Literatura i Kultura Popularna XXIV, Wrocław 2018

DOI: $10.19195 / 0867-7441.24 .13$

\author{
Agnieszka Smoręda \\ ORCID: 0000-0001-7451-0933 \\ University of Łódź
}

\title{
The breakthrough character of The X-Files: Genre hybridity and narrative structure
} television

Keywords: The X-Files, narrative complexity, narrative strategies, genre hybridity, TV series,

Słowa kluczowe: $Z$ Archiwum $X$, złożoność narracyjna, strategie narracyjne, hybrydyzacja gatunkowa, serial, telewizja

The beginning of the 1990s was for the United States a particular time. The end of the Cold War and the lack of an easily identifiable external enemy forced many Americans to focus on the country's internal problems. ${ }^{1}$ At the same time, the entertainment industry, television in particular, began to change as well. The technological evolution made television producers ever so boldly use the achievements of the film industry, such as hand-held cameras, first incorporated in the late 1980s in the TV series Hill Street Blues (created by Steven Bochco, Michael Kozoll, 1981-1987) and popularized in the following decade. ${ }^{2}$ For television's Big Three - NBC, ABC, and CBS - new competition emerged through the creation of Fox Broadcasting Company. It began broadcasting in 1986 and only seven years later, in January 1993, FOX started offering original programming seven days a week, thus gaining the status of a broadcasting network. In the fall of the same year, The X-Files (created by Chris Carter, 1993-2002, 2016-2018), a defining series of the 1990 s, debuts.

The purpose of the following article is to examine the innovative character of the series, using on the one hand genre theory and on the other, David Bordwell's historical poetics adapted by Jason Mittell "to understand the formal storytelling

${ }^{1}$ L. Geraghty, American Science Fiction Film and Television, Oxford-New York 2009, p. 85.

2 S. Turnbull, "Crime as entertainment: The case of the TV crime drama", Continuum: Journal of Media and Cultural Studies 6, 2010, p. 824. 
techniques employed by television series, placing those choices in the context of the industry and its creative personnel to understand why meaning making happens the way it does in these televisual texts". ${ }^{3}$ To prove The X-Files' breakthrough character, I will analyze its genre, describing the characteristics it drew from both the police procedural and science-fiction genre, creating its hybridity. Then, I will consider the series' narrative strategies, focusing on the episodic/ serialized tension resulting in the narrative complexity of the show. While exploring the narrative strategies, I will also describe how the creators of the series used various tools, such as narrative special effects, mini arcs, and bridge episodes and how they utilized two distinctive storytelling modes, mythology-building and self-contained episodes, to create the unique nature of the series.

In my analysis, I will focus on the original run of the series throughout the first nine seasons broadcast between 1993 and 2002. I will omit the final two seasons produced in years 2016-2018. The reason for it being the goal of the analysis: the breakthrough character of the series, which was then imitated by others in terms of narrative strategies and genre-mixing. By including in my analysis the final two seasons of Chris Carter's TV series, I would mangle its results, given that The X-Files revival should be considered in the context of the changes in American television that have happened during the 14 years that passed since the show's cancellation. Hence, its reboot in 2016 should be analyzed in context of nostalgia and the idea of recycling in the era of remakes, reboots, sequels, and prequels, that is the contemporary entertainment industry, and thus, will not be considered in this article.

The article focuses on the groundbreaking character of The X-Files series but its goal is not to limit the innovative achievements of the television of the 1990s to this series alone. Another important TV series of that time that is worth mentioning in this regard is Twin Peaks (created by David Lynch, Mark Frost, 1990-1991, 2017-), which also incorporated supernatural and genre-mixing in to prime time setting. However, several aspects need to be noted that distinguish its role in television history from the one of The X-Files. Twin Peaks was created by the then already established film auteur, using independent cinema techniques and his very unique style in broadcast television. Furthermore, the series, while boldly adding the surreal elements to its plot and visuality, is more straightforward in its narrative structure that is mostly serialized with one plotline of the Laura Palmer murder spanning the entire first season and one third of the second season. While The X-Files popularity grew from season to season, Twin Peaks quickly declined in popularity and got cancelled after 29 episodes. Its legacy is nonetheless unquestionable, albeit in a different field. While The X-Files inspired countless network shows, Twin Peaks could be considered the first instance of American television

3 J. Mittell, Complex TV: The Poetics of Contemporary Television Storytelling, New York-London 2015, p. 339. 
splitting into more broadly appealing broadcasting productions and niche cable shows. But that would be the subject of a different article altogether.

The X-Files is a TV series about two FBI agents, Fox Mulder - an Oxford-educated behavioural psychologist, conspiracy theories enthusiast, and believer in paranormal and supernatural occurrences. Mulder suffered through childhood trauma when his 8-year-old sister was abducted by - as Mulder believes the aliens. The second FBI agent is Dana Scully, a medical doctor and member of the Catholic congregation, who is assigned to the titular X-Files section of the Bureau, in which Mulder is working, to debunk his theories and, as he himself puts it, "spy on him", i.e. to report to their supervisors on his actions. The couple of supposedly opposite characters solves crimes of supernatural nature, while trying to uncover The Truth - discover and find proof of the Government-involved conspiracy and cover-up of the alien invasion and experimentation.

The series defies traditional genre classifications. On the one hand, it uses paranormal and supernatural occurrences, and iconography usually found in science-fiction genre, such as aliens and flying saucers. On the other hand, the protagonists are law enforcement agents and investigate criminal acts, akin to the typical crime drama or cop show. Their relationship even resembles relations between buddy-cop characters, albeit with a romantic subtext. The early 1980s is the emergence of the so-called quality television drama, which initially was heavily rooted in shows of criminal, medical, or legal themes. The TV shows in this category were considered to be serious and prestigious while science fiction was still regarded as simplistic and children-oriented. ${ }^{4}$

Since genre classification has impact on how any given TV series is viewed and interpreted by the audience, ${ }^{5}$ FOX and the producers of The X-Files took risks when they decided to mix multiple conventions together. As Lacy Hodges puts it, the series combined mainstream genres, like crime drama and sitcom, with marginalized ones, like science fiction and horror. ${ }^{6}$ She concludes that "[b]y utilizing the detective story tradition as the basis for many of its science fiction and horror stories and situating its narrative in the real world, The X-Files was able to appeal to mainstream audiences without being labeled as just a genre show. In fact, by combining these two traditions, it was able to use the tropes of science fiction while maintaining its mainstream legitimacy, thereby integrating into the mainstream science fiction traditions that had been largely marginalized in other TV series"?

${ }^{4}$ L. Hodges, "Mainstreaming marginality: Genre, hybridity and postmodernism in The X-Files", [in:] The Essential Science Fiction Television Reader, ed. J.P. Telotte, Lexington 2008, p. 234.

5 J. Bellon, "The strange discourse of The X-Files: What it is, what it does, and what is at stake", Critical Studies in Mass Communication 2, 1999, p. 137.

${ }^{6}$ L. Hodges, op. cit., p. 231.

${ }^{7}$ Ibid., s. 234. 
The X-Files is often summed up by the statement that it is a crime drama in which the question of "Who done it?" is overshadowed by the question "What is it?". ${ }^{8}$ However, it would be a mistake to think about The X-Files as a police procedural with science fiction elements. The difference in approach is most visible when we consider the few standalone episodes of the series, i.e. without any supernatural elements, in which Mulder and Scully follow a more typical case of the week. The example of such approach is Irresistible (S02E13), in which Scully and Mulder are sent to Minneapolis in order to investigate desecrated graves, with corpses dug up and with their hair and nails removed. There is no suspense or question of responsibility since the culprit is revealed in the first scene of the episode. There is no mystery in the nature of the crime, since Mulder immediately profiles the suspect correctly. Hence, the audience is subjected to simply following the actions of the protagonists like in a traditional crime show that enables its audience to "investigate" along with the characters.

According to Robert J. Thompson, the cop show, with its formula, rules, and time constraints, has become the apotheosis of the storytelling medium. ${ }^{9}$ The genre developed from film noir, Public Service Announcements and documentaries, ${ }^{10}$ thus combining entertainment and educational aspects. ${ }^{11}$ The first popular representative of the genre was Dragnet (created by Jack Webb, 1951-1959). Dragnet is an example of a series strongly rooted in reality - the investigations presented during its run were dramatizations and re-enactments of real-life crimes solved by the Los Angeles Police Department. The series promoted community efforts and team work. That changed in the 1960s and 1970s, when more emphasis was put on individual achievements of policemen and the simultaneous inefficiency of the whole system. ${ }^{12}$ Then in the 1980s, the aforementioned Hill Street Blues started the trend of mixing more and less prestigious genres by introducing the elements of sitcom and soap opera to its format. ${ }^{13}$ Furthermore, the producers of Hill Street Blues were the first ones to realize the commercial benefits of targeting an audience most appealing to advertisers. ${ }^{14}$ The X-Files followed suit, attracting the highest percentage of the upper-middle class households of any TV show at that time. ${ }^{15}$

${ }^{8}$ K. Seibel, “This is not happening': The multi-layered ontology of The X-Files", [in:] Narrative Strategies in Television Series, eds. G. Allrath, M. Gynnich, New York 2005, p. 115.

${ }^{9}$ R.J. Thompson, Television's Second Golden Age: From Hill Street Blues to ER, New York 1996, p. 31

${ }^{10}$ S. Turnbull, op. cit., p. 822.

11 Ibid., p. 823.

12 J. Mittell, Genre and Television: From Cop Shows to Cartoons in American Culture, New York-London 2004, p. 151.

13 R.J. Thompson, op. cit., p. 57.

14 Ibid., p. 67.

$15 \mathrm{Ch}$. Soukup, "Television viewing as vicarious resistance: The X-Files and conspiracy discourse", Southern Communication Journal 68, 2002, no. 1, p. 15. 
Police shows are based on the premise of a simple scheme: the procedural character and a repetitive formula built around a criminal investigation. According to Agnieszka Ogonowska, this genre's schematic nature strengthens its audience's belief in the justice of the world, with which they associate the world of the TV series they follow. ${ }^{16}$ The pleasure of watching police procedurals is drawn from the genre's combination of familiar elements, such as returning characters, with the unfamiliar - the crime investigation solved by the end of the episode. ${ }^{17}$ A similar case can be made for most of The X-Files' episodes, which — to a certain extent - imitate the formula of police procedurals. What distinguishes the show from traditional representations of the genre is its inherent ambiguity and improbability of the events it depicts. ${ }^{18}$

Regardless of its massive popularity with the fans of the science-fiction genre, The X-Files is not a model example of the genre, due to its use and depiction of science itself. Oftentimes the use of science and science-based phenomena is instrumental and limited to the use of science-fiction iconography. As noted by Joe Bellon, the mysteries are more often than not left unresolved, without conclusion, ${ }^{19}$ due to the series' unwillingness to explain its reality. ${ }^{20}$ One of the examples of such an approach can be found in one of the earliest episodes of the series, titled Shadows (S01E06), in which an office worker is haunted by the ghost of her murdered boss. The ghost's goal is to find his murderers and take revenge. During the investigation, Scully and Mulder visit a morgue to get the results of the autopsy, interview witnesses, or check the surveillance footage - just as any detective of the police procedural would do. The agents are able to solve the case: the man was killed by his business partner, who conspired with terrorists from the Middle East in illegal purchases of military technology. However, by the end of the hour the question of how the ghost came to be is left unanswered, a question any traditional science-fiction series would at least try to address with a scientific explanation.

Tzvetan Todorov claims that one of the defining features of the genre is its Wonder that can be rationally explained, even if it is according to the yet unknown laws. ${ }^{21}$ Therefore, the purpose of science-fiction genre is not a faithful reflection of reality, but the creation of a world based on a coherent system of laws and rules rooted in science. To distinguish between different approaches to science in genre productions, Forrest J. Ackerman, the editor of one of the pulp magazines, coined

${ }^{16}$ A. Ogonowska, "Sophisticated crime story — przyczyny (potencjalnej) popularności gatunku w Polsce", [in:] Post-soap. Nowa generacja seriali telewizyjnych, a polska widownia, eds. M. Filiciak, B. Giza, Warszawa 2011, p. 12.

17 S. Turnbull, op. cit., pp. 825-826.

18 D. Kellner, "The X-Files and the aesthetics and politics of postmodern pop", The Journal of Aesthetics and Art Criticism 57, 1999, no. 2, p. 173.

19 J. Bellon, op. cit., p. 138.

${ }^{20}$ Ibid., p. 140.

${ }^{21}$ K. Loska, "Czekając na apokalipsę — wizje przyszłości w filmie science fiction”, [w:] Kino gatunków. Wczoraj i dziś, ed. K. Loska, Kraków 1998, p. 134. 
the term "sci-fi". Contrary to science fiction, sci-fi does not attribute any special importance to explaining the science and technology described in it, instead focusing on dazzling its audience with a spectacle. ${ }^{22}$

In that case, should The X-Files be called a science fiction series or rather a sci-fi show? Is it a police procedural with a sci-fi/sf twist? In the 1990s most television shows functioned within clearly established conventions. ${ }^{23}$ Meanwhile, the TV series created by Chris Carter breaks and modifies them by borrowing aspects of many varied genres, from police procedural, to science fiction and horror, to soap opera and sitcom, and creates something new and original in the process. The X-Files constantly changes and shifts its perspective. The series achieved its success by finding a space between mainstream and cult television. Using the flexible and adjustable elements to change the nature of the science-fiction genre, ${ }^{24}$ Carter and his associates adapted it to the modern television market. This difficult art of balancing between conventions was possible to a large extent thanks to contemporary narrative strategies applied to the series.

The 1970s mark the early experiments with the use of the continuous plot developed from one episode to another in a drama series. The first such show was Rich Man, Poor Man (writen by Dean Riesner, 1976), depicting the lives of two second-generation immigrant brothers. The incredible success of the series proved to the TV executives that the audience is able to follow the events from one installment to the other. ${ }^{25}$ It took two more decades before TV writers fully embraced these experimentations with form and narrative structure. It was in the 1990s when the voiceover narration or the unreliable narrator was popularized. Thanks to technological development, the techniques such as intermediality of metafictionality started to be incorporated. ${ }^{26}$ The X-Files did not shy away from using them. The voiceover narration performed by Scully (mainly in the first season) was, according to Chris Carter, used to emphasize that the events are presented from her point of view. ${ }^{27}$ However, the authority she gains in the process is only illusory, ${ }^{28}$ as the voiceover narration is usually her reporting to the superiors who undermine any findings of the FBI agents and focus solely on debunking Mulder's beliefs. What is more, from the second season onward it is Mulder who narrates more episodes, usually in the form of sharing his thoughts with his partner, which

22 O. De Los Santos, "Irwin Allen's recycled monsters and escapist voyages", [in:] Channeling the Future: Essays on Science Fiction and Fantasy Television, ed. L. Geraghty, Plymouth 2009, p. 26.

23 D. Kellner, op. cit., p. 162.

${ }^{24}$ K.M. Booker, Science Fiction Television, Westport 2004, p. 147.

25 R.J. Thompson, op. cit., p. 33.

${ }^{26}$ G. Allrath, M. Gynnich, C. Surkamp, "Introduction: Towards a narratology of TV series", [in:] Narrative Strategies in Television Series, eds. G. Allrath, M. Gynnich, New York 2005, p. 4.

27 J. Bellon, op. cit., p. 150.

${ }^{28}$ K. Seibel, op. cit., p. 120. 
interestingly changes the point of view of the series from the sceptic Dana Scully to Fox "I want to believe" Mulder.

The series has also popularized, what Jason Mittell calls "narrative special effects". ${ }^{29}$ Temporal action shift is one of them, popularized in the next decade by Alias (created by J.J. Abrams, 2001-2006). It takes place when an episode begins with a flashforward to a cliffhanger, towards which the rest of the episode leads. Colony (S02E16), for example, begins with Mulder's voiceover narration about his sister's abduction and the lengths to which he is willing to go to in order to find out The Truth, while we witness him suffering from severe hypothermia and being transported to what appears to be a military field hospital. Moreover, Scully arrives unexpectedly claiming that the hypothermia is keeping Mulder alive. After the opening credits, the title cards inform us that action takes places two weeks before the events of the cold opening and it takes almost two entire episodes for the events to catch up to the ones depicted at the beginning of Colony.

The episodes of The X-Files can be split between two distinctive categories: the ones developing the mythology of the series (the mytharc) and self-contained stories (standalone). The first category consists of episodes focused on the story arc of alien invasion on Earth, the abductions and experiments, and the international conspiracy and government cover-up of the alien presence. The first two episodes of the show (Pilot [S01E01] and Deep Throat [S01E02]) introduce this story arc and provide basic information. We meet Scully and Mulder, learn about their past, backgrounds, and what motivates them. The audience also learns about the conspiracy and the government involvement, responsible for destroying or hiding the evidence of the invasion deep in the Pentagon vaults. The second episode introduces the first informant of the series, Deep Throat (it is worth noting that the series often references the Watergate scandal of the 1970s). The alien/conspiracy plot is developed throughout all of the mytharc episodes across all nine seasons of the original show. The mytharc episodes happen irregularly in each season but always make up at least one fifth of all episodes, from five in the first season to ten in the eighth.

The self-contained episodes, the plot of which commences, develops, and is resolved by the 45-minute mark, are part of the second category of The X-Files episodes. Their structure is borrowed from the police procedurals, where such standalone-type installments are called case-of-the-week episodes. Due to the particular nature of the cases Mulder and Scully investigate on the show, in the context of the series they are called monster-of-the-week. The very first episode of this kind is Squeeze (S01E03), in which Scully is contacted by her friend from the FBI academy, who asks for her help with the investigation into a series of murders, the victims of which have their livers torn out. Mulder quickly suggests supernatural explanation: given that similar murders took place twice before, 30 and 60 years

29 J. Mittell, Complex TV..., p. 43. 
prior to the events of the episode, he suggests that the murderer is over 100 years old and needs the livers to maintain his longevity. Together with Scully he quickly finds a suspect. In Squeeze one of the axes of conflict of the series is outlined, that is the incompetence of other law enforcement officers that spans from local sheriffs to co-workers of Mulder and Scully in the FBI.

This incompetence is one of the three recurring motifs throughout the series in the monster-of-the-week episodes. It is also illustrated in the Irresistible, an episode mentioned before. The local FBI director is introduced watching a game of American football during his working hours. When Scully and Mulder arrive, he does not turn the TV off but turns down the volume instead. During his conversation with the protagonists he constantly glances at the screen. When Mulder assesses the danger, the man takes little to no action while informing Mulder that "It's not New York", meaning that he cannot do anything throughout the weekend and may be able to gather a team "around Tuesday".

Apart from the incompetence of the law enforcement officers, the standalone episodes of The X-Files also contain new clues and evidence of the conspiracy that is the theme of the mytharc episodes. The audience gets to see more proof (Ice [S01E08]), other federal agents interfering with the investigations (Conduit [S01E08]) or intervening without identifying themselves (Shadows [S01E06]) just to name a few examples from the first season alone. The third motif is the potential romantic relationship between Scully and Mulder, who soon become, along with Ross and Rachel from Friends (created by David Crane, Marta Kauffman, 1994-2004), the ultimate will-they-won't-they TV couple. As soon as in the fifth episode of the series (The Jersey Devil [S01E05]) this question is mentioned by Scully's sister. As the series progressed and its popularity rose, the fandom invested in the relationship between their two favorite TV characters (aka shippers), got bigger. This made the creators of the series bolder in their nods to the audience with episodes like Arcadia (S06E15) providing the ultimate fan service. In Arcadia, Mulder and Scully are forced to go undercover, posing as a married couple in a closed-off suburban community, to investigate mysterious disappearances of other couples.

The creation of these three recurring motifs, linking the standalone episodes to the mythology-building ones served two purposes. First of all, the unresolved melodramatic relationships in procedural series are used to make sure the audience will continue to watch the series. ${ }^{30}$ Secondly, they merge two categories together, creating an innovative mix of serial and series narrative strategies. That causes Jason Mittell to claim that The X-Files was the best emanation of narrative complexity, that is the mutual interaction of the episodic and serial formats. ${ }^{31}$

${ }^{30}$ S. Shimpach, Television in Transition: The Life and Afterlife of the Narrative Action Hero, Singapur 2010, p. 36.

31 J. Mittell, Complex TV..., p. 19. 
The final innovative strategy used in The X-Files is the use of multi-episode story arcs. The restrictions in length of an installment of a TV show in broadcast television (i.e. $\mathrm{ABC}, \mathrm{CBS}, \mathrm{NBC}, \mathrm{FOX}$ ) made it impossible to prolong the runtime of an episode if the story called for it. ${ }^{32}$ The writers found a solution to this problem by creating doubled or tripled episodes focused on one narrative mini arc. It served not only as an extension of the story itself but could bridge two seasons together, when a mini arc introduced in the finale of one season, had its climax in the premiere of another. ${ }^{33}$ The series used this strategy for the first time in the second season with Duane Barry (S02E05) and Ascension (S02E06) building the mythology of The X-Files. The first of the two episodes ends on a cliffhanger, when a former FBI agent kidnaps Scully. Ascension continues the arc when Mulder finds the kidnapper but learns that Scully was supposedly abducted by aliens, who took her instead of her kidnapper. The double episode ends with vice-director Skinner re-opening The X-Files section that was dismantled at the end of season one. ${ }^{34}$

The finale of the second season (Anasazi [S02E25]) ends on a cliffhanger as well, when The Cigarette-Smoking Man blows up the underground container in which Mulder was hiding. The fate of the agent stays unclear until the premiere of the third season several months later (The Blessing Way [S03E01]) and the mini arc continues into a triple episode with Paper Clip (S03E02). The penchant for mini arcs was introduced to mainstream TV series with police procedurals like Hill Street Blues and NYPD Blue (created by Steven Bochco, David Milch, 1993-2005) and quickly gained popularity with the science fiction creators. However, the nature of The X-Files is more episodic, since the main plot of the alien

${ }^{32}$ Unlike in cable shows, where TV executives are not so reliant on the advertisement profits, or nowadays in the age of streaming services, enabling its TV creators to obtain more artistic freedom in terms of the runtime. E.g. episodes of Stranger Things (created by the Duffer Brothers, 2016-) run for anything between 42 and 62 minutes.

${ }^{33}$ G. Allrath, M. Gynnich, S. Surkamp, op. cit., p. 11.

34 The structure of the first part of the second season of The X-Files (episodes S02E01S02E08) is due to different strategies employed to cover-up Gillian Anderson's pregnancy. Scully and Mulder are separated, no longer working together in The X-Files, that is nonexistent through one third of the season. Mulder has a new partner, who later turns out to be involved in conspiracy, while Scully, a medical doctor, practices as a criminal pathologist performing autopsies, which makes it easier to hide her pregnancy behind the autopsy table. The plot point of the alien abduction itself, introduced to enable the actress to have a very short maternity leave - she is absent from only one episode, Trinity (S02E07) - had multiple and far-reaching consequences for the entire series. The plot point of the alien abduction and experiments is used in Scully's fight with cancer (Memento Mori [S04E14]) or her mysterious pregnancy (e.g. Requiem [S07E22] and My Struggle $I I I$ [S11E01]). The abduction is also a source of one of the most curious fan theories stating that Scully is immortal, based on Clyde Bruckman's (S03E04, Clyde Bruckman's Final Repose) answer to how she will die, "You don't". 
invasion and the government conspiracy is built "occasionally and implicitly rather than consistently and explicitly". 35

The initial goal of the article was twofold: to explore how the series created by Chris Carter broke with genre conventions, combining multiple elements from various TV genres, most notably the police procedural and science fiction, initiating the popularity of genre hybrids we enjoy today. The second goal was to examine the use of innovative storytelling techniques, mainly the two types of episodes incorporated in the series, as well as mini arcs, bridge episodes, and socalled "narrative special effects" to create the narrative complexity of balancing different story modes. Through the analysis of the series' genre identity and narrative structure I conclude that The X-Files should be considered a groundbreaking TV series due to its combination of mainstream appeal with cult sensibilities and innovative narrative structure. This previously unheard of combination is what made The X-Files a breakthrough series in the history of television, and inspired countless other creators to follow. Klaudia Seibel notes that the series creates the postmodern multiplicity of meanings with its narrative structure. ${ }^{36}$ That is, it leaves its narration open to interpretation, provoking multiple screenings a viewing mode quintessential to 21 st century television. To sum up, The X-Files have revolutionized American television using innovative storytelling techniques and narrative strategies that were employed in a genre-mixing content.

\section{Bibliography}

Allrath G., Gynnich M., Surkamp C., "Introduction: Towards a narratology of TV series", [in:] Narrative Strategies in Television Series, eds. G. Allrath, M. Gynnich, Palgrave Macmillan, New York 2005, pp. 1-46.

Bellon J., "The strange discourse of The X-Files: What it is, what it does, and what is at stake", Critical Studies in Mass Communication 1999, no. 2, pp. 136-154.

Booker K.M., Science Fiction Television, Praeger, Westport 2004.

De Los Santos O., "Irwin Allen's recycled monsters and escapist voyages", [in:] Channeling the Future: Essays on Science Fiction and Fantasy Television, ed. L. Geraghty, Scarecrow Press, Plymouth 2009, pp. 25-40.

Geraghty L., American Science Fiction Film and Television, Berg, Oxford-New York 2009.

Hodges L., "Mainstreaming marginality: Genre, hybridity and postmodernism in The X-Files", [in:] The Essential Science Fiction Television Reader, ed. J.P. Telotte, The University Press of Kentucky, Lexington 2008, pp. 231-246.

Johnson-Smith J., American Science Fiction TV: Star Trek, Stargate and Beyond, I.B. Tauris, London 2005.

Kellner D., "The X-Files and the aesthetics and politics of postmodern pop", The Journal of Aesthetics and Art Criticism 57, 1999, no. 2, pp. 161-175.

35 J. Johnson-Smith, American Science Fiction TV: Star Trek, Stargate and Beyond, London 2005, p. 67.

${ }^{36}$ K. Seibel, op. cit., p. 127. 
Loska K., “Czekając na apokalipsę — wizje przyszłości w filmie science fiction”, [in:] Kino gatunków. Wczoraj i dziś, ed. K. Loska, Rabid, Kraków 1998, pp. 133-141.

Mittell J., Complex TV: The Poetics of Contemporary Television Storytelling, New York University Press, New York-London 2015.

Mittell J., Genre and Television: From Cop Shows to Cartoons in American Culture, Routledge, New York-London 2004.

Ogonowska A., "Sophisticated crime story - przyczyny (potencjalnej) popularności gatunku w Polsce", [in:] Post-soap. Nowa generacja seriali telewizyjnych, a polska widownia, eds. M. Filiciak, B. Giza, Wydawnictwo Naukowe Scholar, Warszawa 2011, pp. 10-26.

Seibel K., "'This is not happening': The multi-layered ontology of The X-Files", [in:] Narrative Strategies in Television Series, eds. G. Allrath, M. Gynnich, Palgrave Macmillan, New York 2005, pp. 114-131.

Shimpach S., Television in Transition: The Life and Afterlife of the Narrative Action Hero, Wiley-Blackwell, Singapur 2010.

Soukup Ch., "Television viewing as vicarious resistance: The X-Files and conspiracy discourse", Southern Communication Journal 68, 2002, no. 1, pp. 14-26.

Thompson R.J., Television's Second Golden Age: From Hill Street Blues to ER, Syracuse University Press, New York 1996.

Turnbull S., "Crime as entertainment: The case of the TV crime drama", Continuum: Journal of Media and Cultural Studies 6, 2010, pp. 819-827.

\title{
TV Series
}

Alias, created by J.J. Abrams, USA 2001-2006.

Dragnet, created by J. Webb, USA 1951-1959.

Friends, created by D. Crane, M. Kauffman, USA 1994-2004.

Hill Street Blues, created by S. Bochco, M. Kozoll, USA 1981-1987.

NYPD Blue, created by S. Bochco, D. Milch, USA 1993-2005.

Rich Man, Poor Man, written by D. Riesner, USA 1976.

Stranger Things, created by The Duffer Brothers, USA 2016-.

The X-Files, created by Ch. Carter, USA, 1993-2002, 2016-2018.

Twin Peaks, created by D. Lynch, M. Frost, 1990-1991, 2017-.

\section{The breakthrough character of The X-Files: Genre hybridity and narrative structure}

\author{
Summary
}

The X-Files should be considered a breakthrough television series, based on its approach to genre hybridity and narrative structure. The series defies traditional genre classifications, combining elements usually attributed to police procedurals, science fiction, and including elements that can be found in horror and sitcom, as well. The article examines how the series mixes these mainstream and cult genres to create a unique genre hybrid attractive to various types of audience. Furthermore, the article analyzes the narrative strategies employed in The X-Files, such as narrative special effects (e.g. voice-over narration) and multi-episode story arcs that engage viewers and bridge seasons. Finally, the balance between two distinctive episode categories (mytharc and standalone/monsterof-the-week) will be discussed to understand the series' innovative character. 